\title{
1 Polyfocal photography of conodonts and other microfossils using \\ 2 petrographic microscopes
}

4 Photographie polyfocale de conodontes et autres microfossiles à l'aide

5 de microscopes pétrographiques

6

7 James F. Miller ${ }^{\mathrm{a}, *}$, Benjamin F. Dattilo ${ }^{\mathrm{b}}$, Raymond L. Ethington ${ }^{\mathrm{c}}$, Rebecca L. Freeman ${ }^{\mathrm{d}}$

$8 \quad{ }^{a}$ Geography, Geology, and Planning Department, Missouri State University, Springfield,

9 Missouri 65897 USA, ${ }^{b}$ Geology Department, Indiana University-Purdue University Fort Wayne

1046805 , USA, ${ }^{\mathrm{C}} \mathrm{Geological}$ Sciences Department, University of Missouri 65211, USA, ${ }^{\mathrm{d}}$ Earth and

11 Environmental Sciences, University of Kentucky 40506, USA

12

$13 *$ Corresponding author

14 email address: jimmiller@missouristate.edu (James F. Miller)

15

16 Keywords:

17 polyfocal photography 
18 petrographic microscope

19 conodonts

20 Cambrian

21 Ordovician

22

23

24

25

\section{ABSTRACT}

26

27 Polyfocal photography is a method for obtaining digital images that have great depth of

28 focus. A series of photos are made at successive focal levels from the bottom to the top of a fossil

29 using reflected light. Computer software takes the part of each image that is in focus and merges

30 all of the parts into a composite image that is entirely in focus. Microscopes designed for this

31 purpose are available but are expensive. A petrographic microscope with a digital camera can

32 produce such a series of images, and they can be composited by an inexpensive computer

33 program. Polyfocal photography appears to be superior to other methods of photography for

34 illustrating conodonts. Composite images show internal features such as basal cavities and white

35 matter, and the software can convert one composite image into a stereoscopic pair. 
40 à grande profondeur de champ. Une série de prises de vue d'un fossile est réalisée en lumière

41 réfléchie à différents niveaux de mise au point depuis le bas vers le haut du spécimen. Un

42 logiciel fusionne alors les éléments nets de chaque image en une unique image composée qui est

43 alors entièrement nette. Les microscopes destinés à cet usage sont couteux. Cependant, un

44 microscope pétrographique équipé d'une caméra numérique peut produire une telle série

45 d'images qui peuvent alors être fusionnées par un logiciel au prix accessible. La photographie

46 polyfocale semble être supérieure aux autres méthodes de photographie pour illustrer les

47 conodontes. Les images composées montrent des caractéristiques internes telles que les cavités

48 basales et la matière blanche, et le logiciel peut convertir une image composée en une paire

49 d'images stéréoscopiques.

50

51 Mots clés:

52 photographie polyfocale

53 microscopes pétrographiques

54 conodontes

55 Cambrien

56 Ordovicien 


\section{Introduction}

59

Methods of illustrating conodonts have changed throughout the last two centuries. Pander

61 (1856) used drawings to illustrate the first recorded conodonts, and Furnish (1938) also

62 illustrated Lower Ordovician conodonts with drawings. Miller (1969) illustrated Cambrian

63 conodonts with light photographs that showed internal features such as shapes of basal cavities

64 and distribution of white matter. A problem with light photography is that depth of focus is

65 limited. Scanning Electron Microscopes became widely available in the 1970s, and most

66 conodont specialists abandoned light photography and adopted SEM micrographs instead. The

67 resulting images had excellent depth of focus and high resolution, and very fine external

68 ornament became visible for the first time. A disadvantage was that only surface features can be

69 illustrated with scanning electron microscopy, and it was necessary to illustrate internal features

70 with line drawings (Fig. 1). Also, specimens were often coated with gold, which obscured

71 internal features and made future study of such features on those specimens difficult or

72 impossible.

73 Polyfocal photography is a relatively new method that shows internal features and has

74 unlimited depth of focus, resulting in high-quality digital images. The method, often referred to

75 as "stacking," uses a series of digital images (a "stack") taken at different focal levels, and

76 computer software then combines the in-focus parts of individual images to form a composite

77 image that is entirely in focus. Specialized microscopes are made for polyfocal photography, but 
78 they are quite expensive. Petrographic microscopes can be used with available computer

79 software to produce similar results.

80 We report on the brands, models, and versions of equipment and programs used to

81 generate images in this paper. This report does not constitute an endorsement of any of these

82 specific brands, models, or versions of equipment.

83

\section{2. Dedicated polyfocal microscope}

85

Our first experience with polyfocal photography was with a Leitz model 205 polyfocal

87 microscope, which utilizes a single objective lens, and lenses with different magnifications can

88 be rotated into position. The microscope stage (rather than the upper part of the microscope) can

89 be focused manually, and it is motorized so that the stage can be focused in small, precise

90 increments. We placed as many as fifteen conodonts close together on a standard cardboard

91 faunal slide without using glue and then positioned the slide on the microscope stage.

92 After manually focusing the microscope on the surface of the cardboard slide, the stage is

93 then manually refocused on the highest part of the mounted conodonts, with the accompanying

94 computer software recording both vertical positions. The computer then calculates the total relief

95 of the specimens and the number of exposures required. Low-relief specimens require perhaps 6-

9610 images taken at different focal levels; high relief fossils require more images. Controlled by

97 the computer software, the motorized stage moves to the lowest position, where the surface of

98 the faunal slide is in focus, and then in successive vertical steps a photograph is taken at each 
99 level until the highest part of the fossil has been photographed. The computer software then

100 selects the part of each slice that is in sharp focus and digitally combines those parts to produce a

101 composite image that is entirely in focus.

102 When the slide is in place on the microscope stage and the vertical coordinates are stored

103 in the computer, it takes only 3-4 minutes to complete a stack of images and to generate the

104 composite image. All of the individual slices and the composite image are stored on the computer 105 and can be transferred to other computers.

106 The process uses reflected light, which penetrates the fossils and is reflected back to the 107 camera, so that the composite image shows internal features such as basal cavities and white 108 matter. Figure 2 shows 14 images that were taken as parts of several stacks. Images on Fig. 2

109 were converted from the original color versions to grayscale using Adobe Photoshop.

110 Specimens on Fig. 2 are topotype specimens of Cordylodus proavus Müller, 1959 from

111 Oklahoma, USA. The Color Alteration Index (CAI) is about 2 (Epstein et al., 1977), meaning

112 there is only moderate darkening of the original color due to heating of the fossils. Figs. $2 \mathrm{~A}-\mathrm{H}$

113 are S (rounded) elements, Figs. 2I, J, L, M are M (compressed) elements, and Fig. 2K is a P

114 (twisted) element. Even in grayscale, the specimens illustrated on Figure 2 show many features

115 not visible in SEM micrographs, such as shapes of basal cavities. Complex distribution of white

116 matter is visible in all of the cusps above the tips of the basal cavities, and the denticles contain

117 white matter. Figs. 2A-K, M illustrate specimens with cusps that are mostly or entirely white

118 matter. Fig. 2L is pathogenic and has little white matter because the cusp was broken during life.

119 A short cusp was regenerated (at tip of arrow), and only the tip of the regenerated cusp is white

120 matter. In Fig. 2J the cusp is white matter, which also fills most of the area anterior to the basal 
121 cavity (at arrow). The cusps of specimens in Figs. 2B-C were broken during life, and the tips

122 were healed together by narrow bands of white matter (at arrows). Fig. 2E shows a similar

123 breakage, but the band of white matter is much wider (between arrows). These bands of white

124 matter appear be secondary apatite that healed broken elements. The specimen in Fig. $2 \mathrm{G}$ shows

125 an unusual knob of white matter that formed above the tip of the basal cavity and fused a small

126 part of the original cusp (at tip of present cusp) together with the area above the basal cavity. The

127 arrow indicates additional white matter deposited anterior to the distal part of the basal cavity.

128 The specimen in Fig. $2 \mathrm{H}$ has the cusp broken just above the tip of the basal cavity, and the cusp

129 was healed in place at an odd angle; a similar repair scar can be seen in Fig. 2 B.

130 None of these complex features would be visible on SEM micrographs, and they would

131 be difficult to illustrate with line drawings. It is clear that polyfocal photography combines some

132 features of normal light photography and SEM photography but is an improvement over both

133 methods. Nevertheless, access to dedicated polyfocal microscopes is not universal because they

134 are quite expensive.

135

136 3. Photography with student-model petrographic microscope

137

138 Dattilo developed a procedure for polyfocal photography of conodonts using a

139 petrographic (polarizing) microscope. He used a student-model Leica DM LSP with a 10x

140 objective, fitted with a Leica DFC 450 digital camera. He mounted on a standard cardboard

141 faunal slide individual conodont elements from the Middle Ordovician Crystal Peak and Watson 
142 Ranch Formations from the Ibex area of western Utah. A fiber-optics illuminator with two

143 flexible cables provided reflected light, and rotating the upper polarizer on the microscope

144 reduced glare. Because petrographic microscopes are intended for studying thin sections of rock,

145 they do not have great depth of focus. However, that shortcoming is overcome by taking a stack

146 of photographs, each of which is partly in focus. The first photograph was focused on the surface

147 of the faunal slide. Subsequent photographs were made by manually rotating the fine-focus ring

148 on the microscope by a specific number of calibration marks, taking another photograph, and

149 repeating the process until the highest part of the fossil was photographed. A stack of $\sim 25$

150 photographs was obtained in this manner.

151 Dattilo downloaded the HeliconFocus computer program from the website

152 www.heliconsoft.com. The company sells licenses to use their software program for different

153 periods of time, although a one-month trial version is available free. An inexpensive lifetime

154 license includes free upgrades; details are on the website. The program can be downloaded onto 155 as many as four different computers, and it is available in versions for Windows and Macintosh

156 operating systems.

157 The stack of digital photographs was copied into the HeliconFocus program, which 158 produced an in-focus composite image in 2-3 minutes. Figure 3 shows a few of the composite 159 images obtained by using this procedure. The color of these conodonts is much darker than their 160 original color $(\mathrm{CAI}=4-5)$, and the species illustrated here were chosen because they have 161 relatively complex morphologies and high relief. Small grains of quartz sand adhere to some of 162 the specimens.

163 Several of the images in Figure 3 required special treatment. Dattilo encountered 
164 a problem generating good composite images of some specimens because the background 165 slide was dark and shiny and the dark conodont had many denticles with high relief, such 166 as the specimen in Fig. 3A. Another part of the problem was that some conodonts that he 167 photographed (e.g. Fig. 3A) had denticles that overlapped each other. The shallow depth 168 of focus of the petrographic microscope caused parts of the conodont to be nearly 169 invisible when the background slide was in focus, or when parts of overlapping denticles 170 were not in focus on the same photograph. Also, the slide was nearly invisible when the 171 highest parts of the conodont were in focus. This situation made it difficult for the 172 computer program to detect the precise outline of the denticles or to bring the background 173 slide into focus, thus producing a poor composite image. HeliconFocus provides a

174 "retouching" tool that allows the user to view the composite image while simultaneously 175 viewing any of the individual slices and "painting" the images to choose which part of 176 which slice will be used to make the composite image. This retouching tool allows the 177 user to eliminate artifacts in the composite image that were generated by the computer 178 program.

179 This was the first experiment using a petrographic microscope, and the 180 background slide was black, and the conodonts were very dark (high CAI). The problem 181 that required retouching probably could be eliminated by using a mounting surface that is 182 not shiny and that has a color that contrasts strongly with the conodont, such as a light 183 background for a dark conodont. However, a perfect background that contrasts well with 184 the color of the conodont will not overcome the high relief of overlapping denticles that 185 is characteristic of a few conodonts. It is possible that carefully orienting conodonts so 186 that denticles do not overlap would avoid that problem. The retouching tool is available 
187 for problems that cannot be avoided with the right background or orientation.

188 The second problem was that the conodont elements in Figs. 3C, H, and I were

189 too long to fit into the field of view of the 10x objective microscope lens, and the

190 specimens required two stacks of images that overlapped along the length of the

191 specimen. The two composite images for those specimens were joined together using

192 Adobe Photoshop.

193

194 4. Photography with research-quality petrographic microscope

195

196 Miller used Dattilo's procedure to photograph conodonts with a research-quality

197 petrographic microscope, Nikon Eclipse Model LV100POL with a 10x objective and Nikon

198 DXM1200C digital camera connected to a computer. This microscope has a built-in reflected

199 light source, and the upper polarizer was rotated to reduce glare. Conodont elements were

200 mounted without glue using several different background surfaces.

201 The first digital photograph was focused on the background, and successive photographs

202 were made after manually rotating the fine-focus ring a specific number of calibration marks

203 between exposures. Focusing had to be made on the computer screen rather than through the

204 microscope lens. Miller first tried refocusing the fine-focus ring by three calibration marks

205 between exposures, but it was determined that refocusing by 6-10 marks between exposures

206 gave results of equal quality. The appropriate number of increments must be determined

207 experimentally due to differences in equipment and fossils. 

which shows topotype specimens of Cordylodus andresi Viira and Sergeyeva in Kaljo et al.

210 (1986). Specimens in Figs. 4A-D are from the same sample as the holotype (Viira et al., 1987);

211 Figs. 4E-I are from the next higher sample. This is the oldest named species of the genus and is 212 the ancestor of C. proavus, shown in Figure 2. Polyfocal photographs of C. andresi on Figure 4 213 can be compared with an image of the same species on Figure 1, which was made using a 214 Scanning Electron Microscope. Morphological details shown on Figure 4 are somewhat different from those on Figure 2.

216 Specimens on Figure 4 are essentially unaltered from their original color $(\mathrm{CAI}=1)$. Figs. 4A-H 217 are $\mathrm{S}$ (rounded) elements; Fig. 4I is an $\mathrm{M}$ (compressed) element. All have black organic matter 218 filling the basal cavities, which extend deeper into the cusp than in Cordylodus proavus (Figure 219 2), and the deeper basal cavity is a characteristic feature of $C$. andresi. Where the black filling is 220 absent, the basal cavities are red. Tiny dark inclusions are visible in some denticles (Figs. 4F, H,

221 I). A general feature of these images is that they show glare along the edges of parts of cusps and 222 denticles; this is especially clear on Fig. 4C, indicated by the arrow. This glare may be related to 223 the rotated plane of the microscope's upper polarizer. Denticles of some elements originate along 224 the side of the cusp (Figs. 4A, D, E) rather than from a distinct posterior process, as is common 225 in C. proavus (Figure 2). Figs. 4C, G show elements in which the cusps have no white matter. 226 Fig. 4B has a cusp that was broken during life and was healed by a tiny, blunt tip of secondary 227 apatite (at arrow). Figs. 4A, D, F display cusps that were broken during life and healed together 228 by thin bands of white matter (at arrows). As in C. proavus, breakage of the cusp in C. andresi 229 occurs just above the tip of the basal cavity. Denticles of specimens in Fig. 3F, G were broken 230 and regenerated (at arrow). Healing illustrated in Fig. 4A left the healed part of the cusp bent at 
231 an angle relative to the rest of the specimen. The specimen in Fig. 4E has an irregularly broken

232 tip of the basal cavity, a partly regenerated cusp, and white matter deposited anterior to the

233 uppermost part of the basal cavity (at arrow). That white matter compares with Fig. 4G. In

234 general, specimens on Figure 4 have little or no white matter, which is a characteristic feature of

235 C. andresi, and the white matter appears to be where pieces of broken cusps were healed

236 together. Elements of C. proavus (Figure 2) have longer cusps than C. andresi, although clearly

237 some elements were broken and mended with white matter, as discussed above.

\section{5. Stereo pairs}

242 a stack of images is converted to a composite image, it can be viewed in a rotating, three-

243 dimensional animation. A stereo pair can also be generated from the single composite image. Fig.

244 5A shows a composite image of a symmetrical element of Fryxellodontus inornatus Miller, 1969,

245 which has an unusually complex three-dimensional morphology for a Cambrian conodont. The

246 specimen was recovered with the topotype specimens of Cordylodus proavus from Oklahoma.

247 Figs. 5B, C are a stereo pair made from the composite image by the HeliconFocus software, and

248 the stereo pair permits the complex morphology to be understood more easily than by viewing 249 multiple images taken from several different angles.

\section{6. Discussion}


254 microscopes are not needed to photograph conodonts because a standard petrographic

255 microscope with a digital camera can be used instead. Polyfocal photography offers insight into

256 internal morphological details that are not seen with SEM imaging. Such illustrations offer the

257 hope of new understanding of such issues as the utility of white matter as a taxonomic character, 258 and the frequency and origin of repair scars. This technology also offers the possibility of easily

259 illustrating specimens as stereo pairs for better understanding of the three-dimensional

260 morphology of complex elements. Paleontologists studying other groups of microfossils, such as

261 acritarchs, chitinozoa, foraminifera, or radiolaria, may be able to use other kinds of microscopes

262 equipped with digital cameras to produce composite images that are a significant improvement

263 over single-image photographs.

264

\section{Disclosure of interest}


272 National Science Foundation award 0642405 provided funds to purchase the Nikon petrographic

273 microscope that Miller used to photograph the Estonian specimens. John Cutler helped collect

274 the conodont samples that yielded specimens illustrated in Figure 3. Michelle Miller and Mario

275 Daoust provided French translations. Gabriella Bagnoli and an anonymous person made several

276 helpful suggestions in their reviews of the original manuscript.

\section{References}

Epstein, A.G., Epstein, J.B., Harris, L.D., 1977. Conodont Color Alteration-an index to organic metamorphism. U.S. Geological Survey Professional Paper 995, 27 p.

282 Furnish, W.M., 1938. Conodonts from the Prairie du Chien beds of the Upper Mississippi Valley. Journal of Paleontology 12, 318-340.

284 Hadding, A.R., 1913. Undre dicellograptusskiffern i Skåne jämte någre dårmed ekvivalenta 285 bildningar. Lunds Universität Årsskrifter 2 (15), 90 p.

286 Harris, R.W., 1962. New conodonts from the Joins (Ordovician) Formation of Oklahoma. Oklahoma Geology Notes 22, 199-211.

Kaljo, D., Borovko, N., Heinsalu, H., Khazanovich, K., Mens, K., Popov, L., Sergeyeva, S., Sobolevskaya, R., Viira, V., 1986. The Cambrian-Ordovician boundary in the Baltic-Ladoga clint area (North Estonia and Leningrad Region, USSR). Eesti NSV Teaduste Akadeemia Toimetised, Geoloogia 35, 97-108. 
292 Miller, J.F., 1969. Conodonts from the Notch Peak Limestone (Cambro-Ordovician), House 293 Range, Utah. Journal of Paleontology 43 (2), 413-439.

294 Miller, J.F., Evans, K.R., Freeman, R.L., Ripperdan, R.L., Taylor, J.F., 2011. Proposed stratotype 295 for the base of the Lawsonian Stage (Cambrian Stage 10) at the First Appearance Datum 296 of Eoconodontus notchpeakensis (Miller) in the House Range, Utah, USA. Bulletin of 297 Geosciences $86(3), 595-620$.

298 Müller, K.J., 1959. Kambrische Condonten. Zeitung Deutsche Geologische Gessellschaft 111, $299 \quad 434-485$.

300 Mound, M.C., 1965. A conodont fauna from the Joins Formation (Ordovician), Oklahoma.

$301 \quad$ Tulane Studies in Geology 4 (1), 46 p.

302 Pander, C.H., 1856. Monographie der fossilen Fische des silurischen Systems der russische303 baltischen Gouvernements. Buchdruckeri der Kaiserlichen Akedemie der Wissenschaften, 304 St. Petersburg, 91 p.

305 Viira, V., Sergeyeva, S., Popov, L., 1987. Earliest representatives of the genus Cordylodus 306 (Conodonta) from Cambro-Ordovician boundary beds of north Estonia and Leningrad 307 region. Proceedings of the Academy of Sciences of the Estonian SSR, Geology 36, 145$308 \quad 153$.

309

310

311

312 
315 Figure 1. Scanning Electron Microscope lateral views and drawings of conodonts from the Lava

316 Dam Member of the Notch Peak Formation, House Range, Utah. A, B. S (rounded) element of

317 Cordylodus andresi Viira and Sergeyeva in Kaljo et al. (1986) from sample SP-6-49, from 84.1

$318 \mathrm{~m}$ above the base of the Steamboat Pass section, at the base of the Cordylodus proavus Zone. C,

319 D. Geniculate element of Cambrooistodus minutus (Miller, 1969) from sample LD5-LD-131,

320 from $61.9 \mathrm{~m}$ above the base of the Lava Dam Five section, near the top of the C. minutus

321 Subzone of the Eoconodontus Zone. Scale bar of $200 \mu \mathrm{m}$ is for all specimens. Modified from

322 Miller et al. (2011, Fig. 7). The specimens are reposited at the University of Iowa Paleontology

323 Museum (acronym SUI), Iowa City, Iowa, USA. A: SUI 125996, C: SUI 125995.

324 Vues latérales par microscopie électronique à balayage et dessins de conodontes du Membre

325 Lava Dam de la Formation de Notch Peak, House Range, Utah, États-Unis. A, B. Élément S

326 (arrondi) de Cordylodus andresi Viira et Sergeyeva dans Kaljo et al (1986) de l'échantillon SP-

327 6-49, à 84.1 mètres au-dessus de la base de la section Steamboat Pass, base de la zone

328 Cordylodus proavus. C, D. Élément géniculé de Cambrooistodus minutus (Miller, 1969) de

329 l'échantillon LD5-LD-131, à 61.9 mètres au-dessus de la base de la section Lava Dam Five, près

330 de la limite supérieure de la sous-zone Cambrooistodus minutus de la zone Econodontus.

331 Modifié de Miller et al (2011, Fig. 7). Les spécimens sont conservés au musée de paléontologie

332 de l'Université d'Iowa (acronyme SUI), Iowa City, Iowa, États-Unis. A, B: SUI 125996; C, D: SUI 333125995. 
335 Figure 2. Polyfocal lateral views of topotype specimens of Cordylodus proavus Müller, 1959

336 from $6 \mathrm{~m}$ below the top of the Signal Mountain Limestone on the Chapman Ranch, Arbuckle

337 Mountains, Oklahoma, USA. A-H. S (rounded) elements. I-J, L-M. M (compressed) elements

338 (L, pathologic). K. P (twisted) element. Arrows indicate features of special interest discussed in 339 text. Images show shapes of basal cavities and distribution of white matter. Scale bar of $200 \mu \mathrm{m}$

340 is for all specimens. Specimens are in the collection of J.F. Miller, Missouri State University,

341 Springfield, Missouri, USA.

342 Vues polyfocales latérales de spécimens topotypes de Cordylodus proavus Müller, 1959, à $6 \mathrm{~m}$ 343 au-dessous de la limite supérieure du Calcaire de Signal Mountain sur le Chapman Ranch, dans 344 les montagnes Arbuckle, Oklahoma, États-Unis. A-H. Éléments S (arrondis). I- J, L-M. Éléments

345 M (comprimés ; L, pathologique). K. Élément P (tordu). Les flèches indiquent les points d'intérêt 346 mentionnés dans le texte. Les images montrent la silhouette des cavités basales et la distribution 347 de la matière blanche. La barre d'échelle de 200 um concerne tous les spécimens. Les spécimens 348 sont conservés dans la collection de J.F. Miller, Missouri State University, Springfield, Missouri 34965897 USA.

350

351

352 Figure 3. Polyfocal views of some species of conodonts from the Crystal Peak Formation (A) 353 and the Watson Ranch Formation (B-I) in western Utah, USA. A, F. posterior views. B-E, G-I.

354 Lateral views. A, E. Erraticodon alternans (Hadding, 1913). B. Apteracontiodus sinuosus

355 (Mound, 1965). C, G-I. Paraprioniodus costatus (Mound, 1965). D. Drepanoistodus angulensis

356 (Harris, 1962). F. Histiodella sp. Scale bar of $200 \mu \mathrm{m}$ is for all specimens, and a human hair is 
357 shown for comparison. Specimens are in the collection of R.L. Ethington, Geological Sciences

358 Department, University of Missouri, USA.

359 Vues polyfocales de quelques espèces de conodontes de la Formation de Crystal Peak (A) et de

360 la Formation de Watson Ranch (B-I) dans l'ouest de l'Utah, États-Unis. A, F. Vues postérieures.

$361 B-E, G-I$. Vues latérales. A, E. Erraticodon alternans (Hadding, 1913). B. Apteracontiodus

362 sinuosus (Mound, 1965). C, G-I. Paraprioniodus costatus (Mound, 1965). D. Drepanoistodus

363 angulensis (Harris, 1962). F. Histiodella sp. La barre d'échelle de $200 \mu$ m est pour tous les

364 spécimens. Un cheveu humain est placé pour comparaison. Les spécimens sont conservés dans

365 la collection de R.L. Ethington, Geological Sciences Department, University of Missouri, USA.

367 Figure 4. Polyfocal lateral views of topotype specimens of Cordylodus andresi Viira and

368 Sergeyeva in Kaljo et al. (1986) from Estonia. All figures from the Kallavera Formation in the

369 Vihula section (Viira et al., 1987). A-D. Sample 5 of Viira et al. (1987). E-I from sample 6 of

370 Viira et al. (1987). A-H. S (rounded) elements. I. M (compressed) element. Arrows indicate

371 features of special interest discussed in text. Basal cavities partly to completely filled with black

372 organic material. Images show shapes of basal cavities and distribution of white matter. Scale bar

373 of $200 \mu \mathrm{m}$ is for all specimens. Specimens are in the collection of J.F. Miller, Missouri State

374 University, Springfield, Missouri, USA.

375 Vues polyfocales latérales de spécimens topotypes de Cordylodus andresi Viira et Sergeyeva in

376 Kaljo et al. (1986) d'Estonie. Tous les spécimens viennent de la Formation Kallavera dans la

377 section Vihula (Viira et al, 1987). A-D. Échantillon 5 de Viira et al. (1987). E-I. Échantillon 6 de

378 Viira et al. (1987). A-H. Éléments S (arrondis). I. Élément M (comprimé). Les flèches indiquent 
379 des points d'intérêt mentionnés dans le texte. Les cavités basales sont partiellement ou

380 entièrement remplies de matière organique noire. Les images montrent la silhouette des cavités

381 basales et la distribution de la matière blanche. La barre d'échelle de 200 um est pour tous les

382 spécimens. Les spécimens sont conservés dans la collections de J.F. Miller, Missouri State

383 University, Springfield, Missouri, USA.

384

385 Figure 5. Symmetrical element of Fryxellodontus inornatus Miller, 1969 from the same

386 Oklahoma sample as specimens on Figure 1. A. Composite polyfocal image.B, C. Stereo pair

387 made from A by HeliconFocus computer program. Scale bar of $200 \mu \mathrm{m}$ is for all views.

388 Specimen is in the collection of J.F. Miller, , Missouri State University, Springfield, Missouri, 389 USA.

390 Élément symétrique de Fryxellodontus inornatus Miller, 1969 du même échantillon d'Oklahoma

391 que les spécimens de la Figure 1. A. Image polyfocale composée. B- C. Paire stéréoscopique

392 faite à partir de A par le logiciel HeliconFocus. La barre d'échelle de $200 \mu$ m est pour toutes les

393 vues. Le spécimen est conservé dans la collection de J.F. Miller, Missouri State University,

394 Springfield, Missouri, USA. 
Figure 1

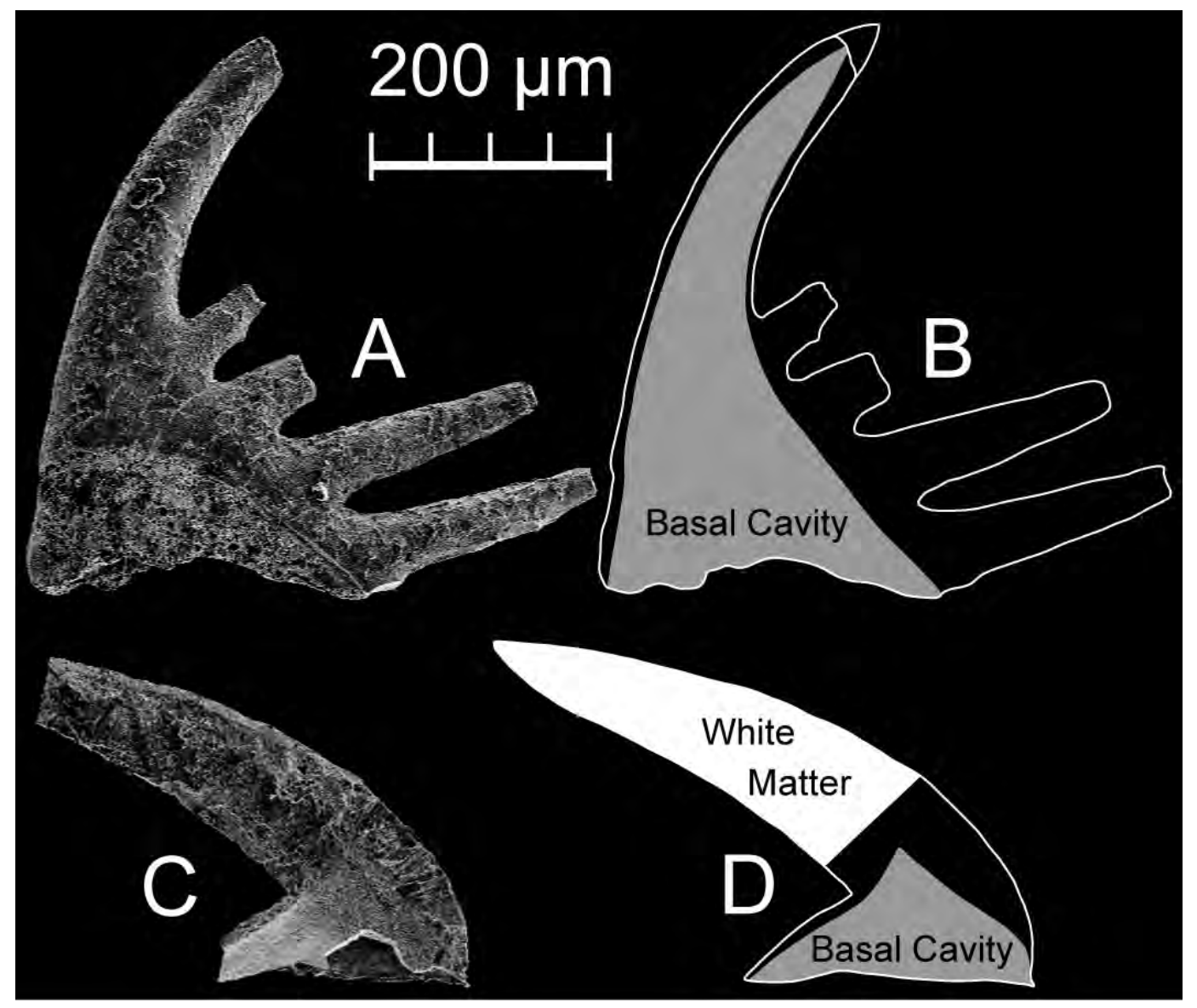


Figure 2

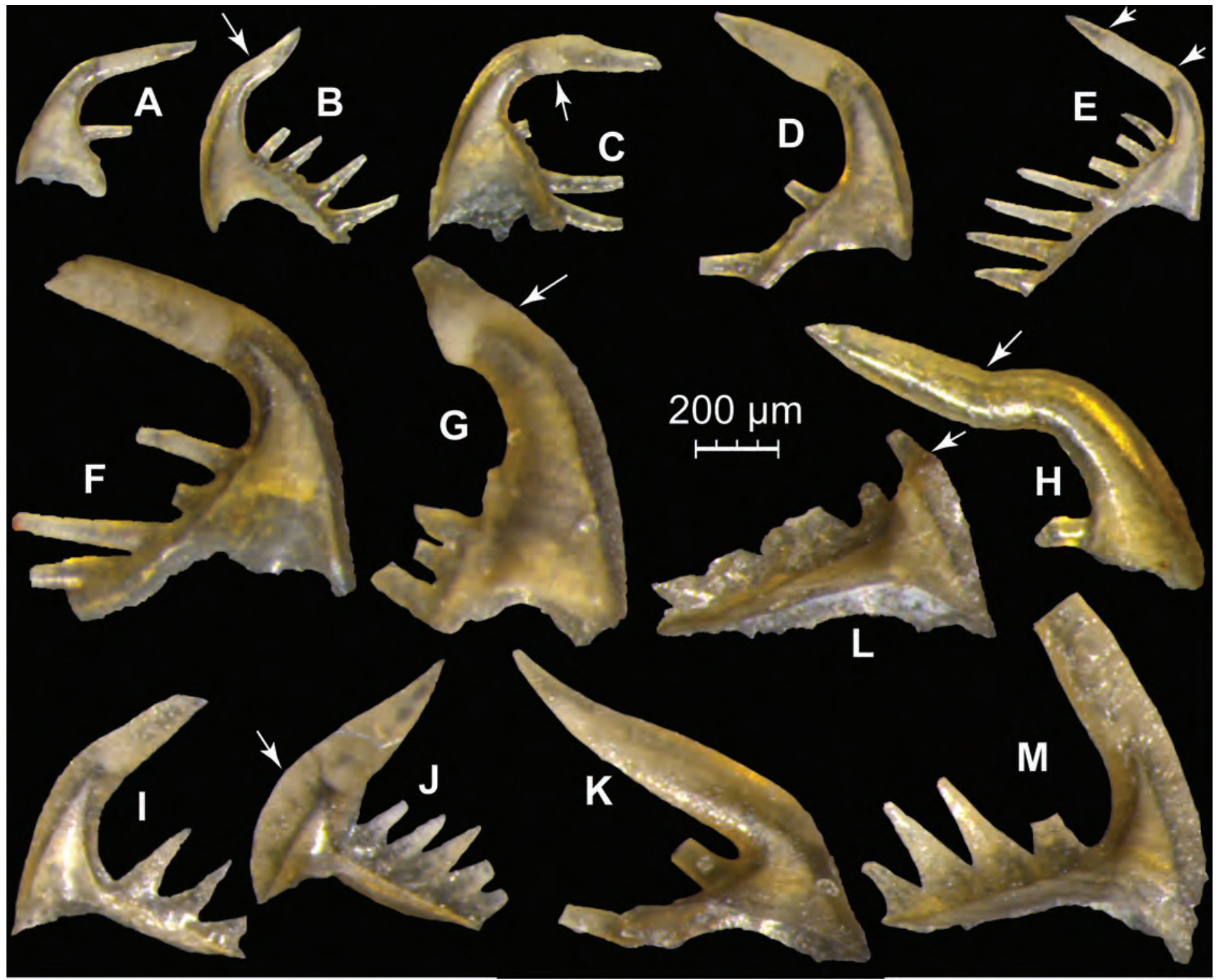


Figure 3

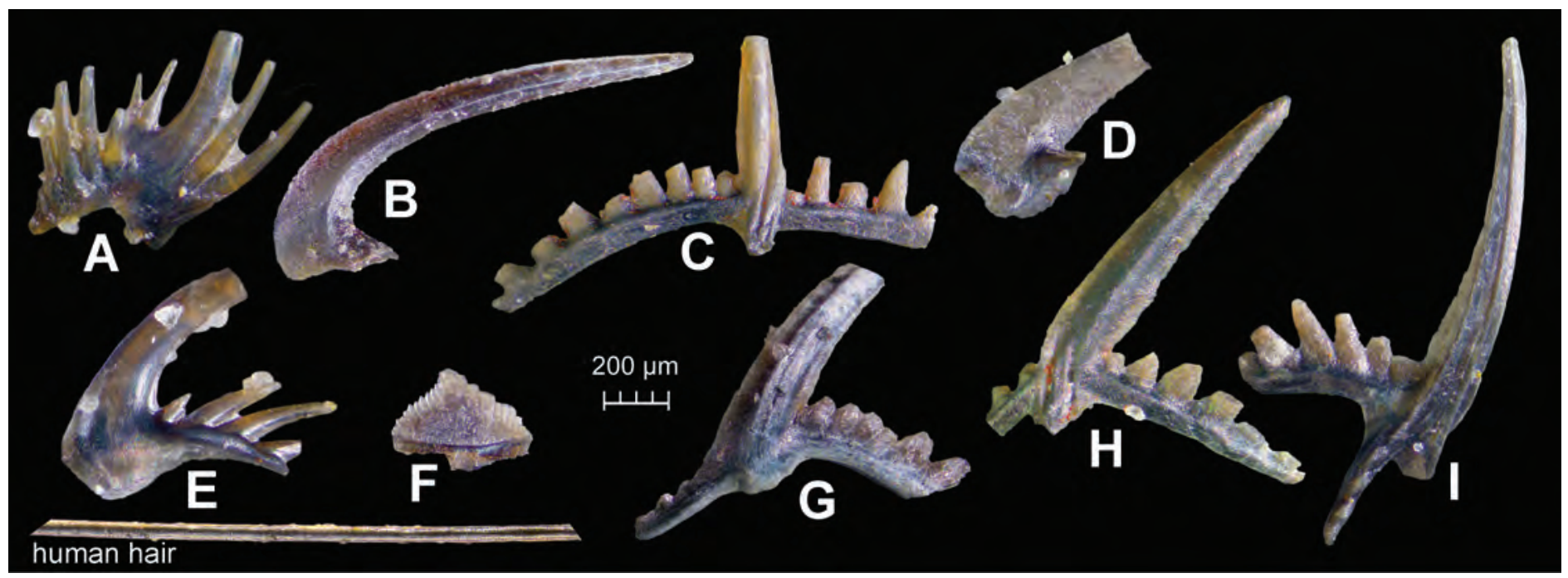


Figure 4

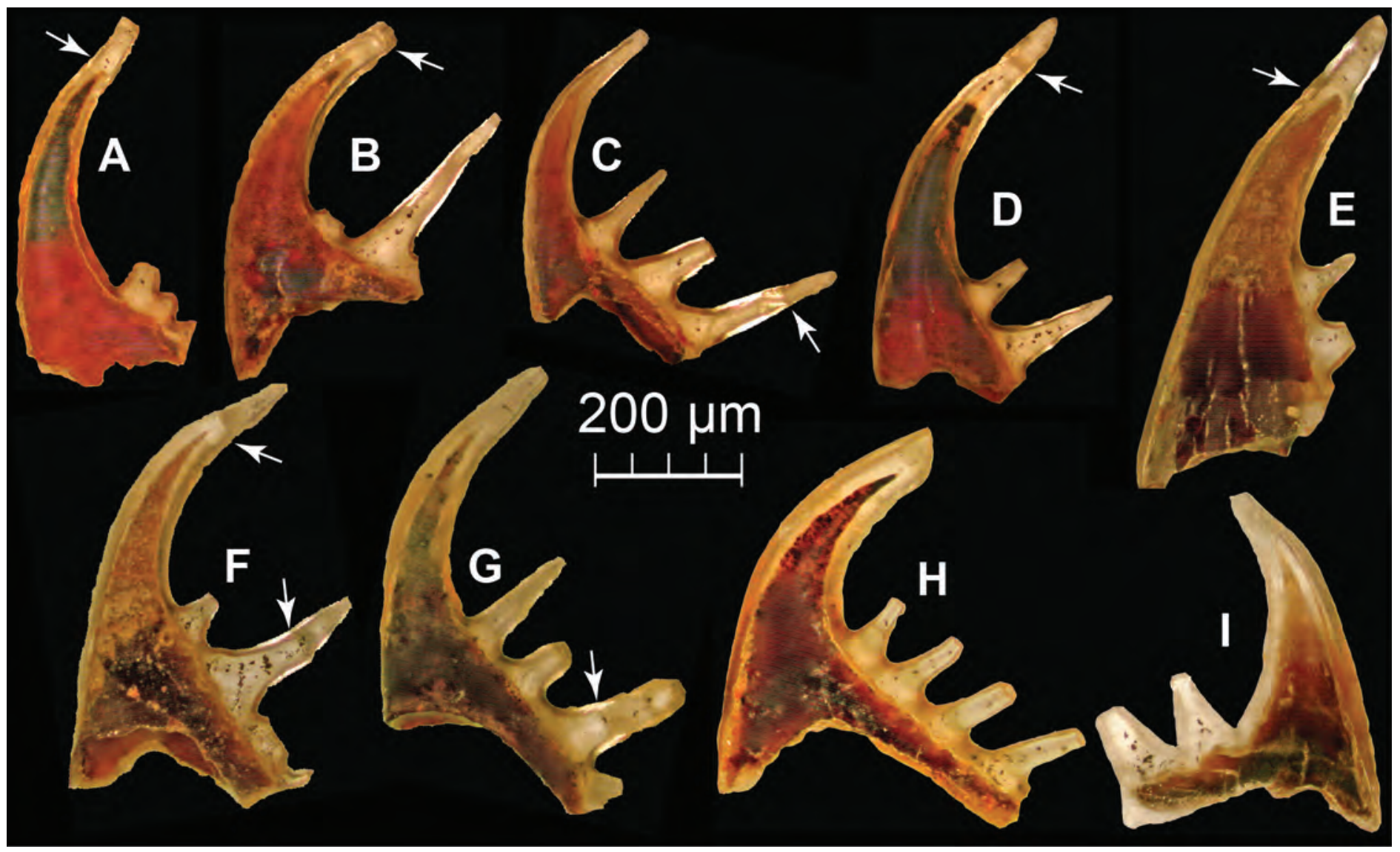


Figure 5

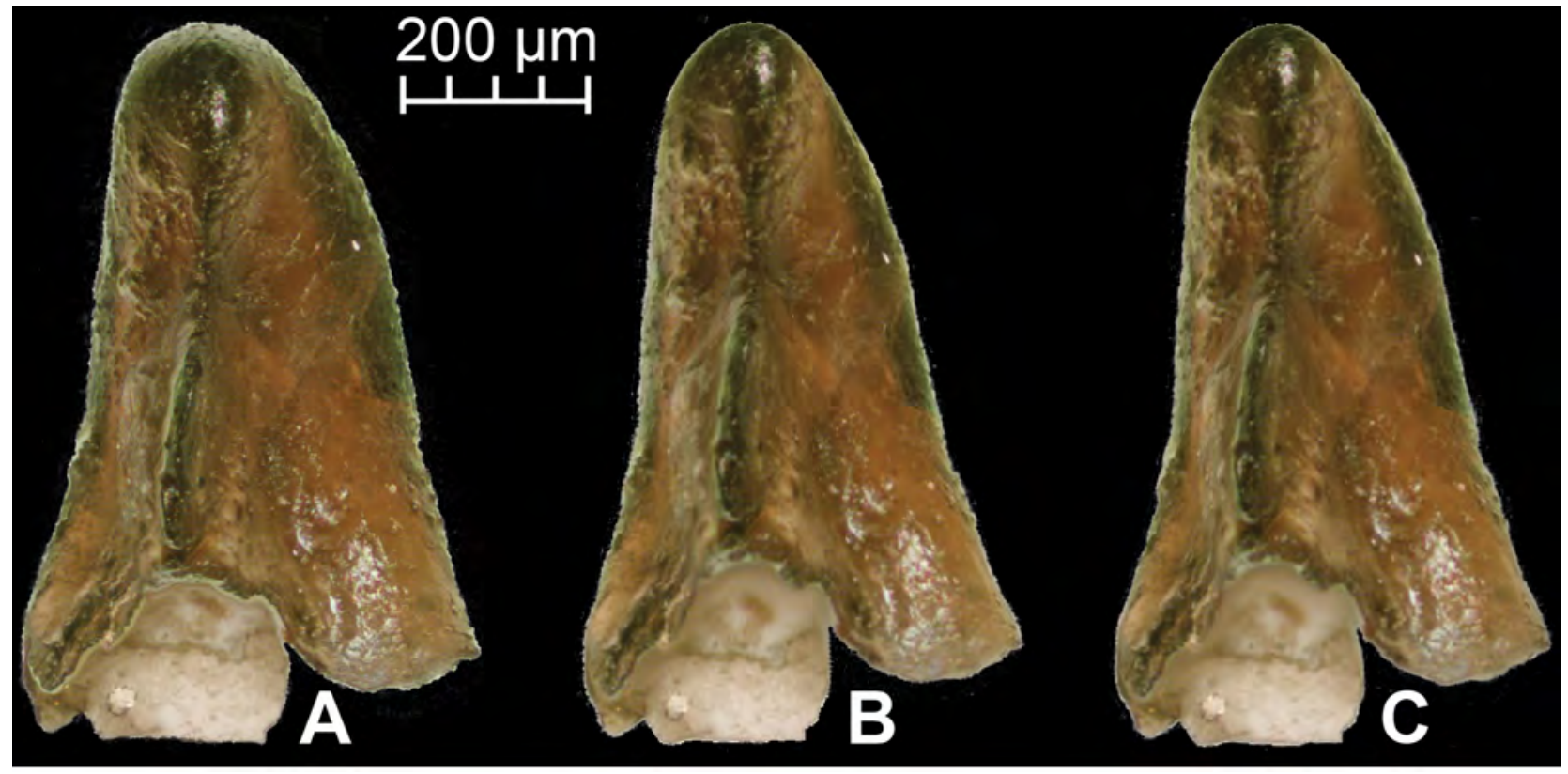

